Bull. Mater. Sci., Vol. 30, No. 1, February 2007, pp. 57-63. () Indian Academy of Sciences.

\title{
Polynitroaniline as brightener for zinc-nickel alloy plating from non-cyanide sulphate bath
}

\author{
H P SACHIN, GANESHA ACHARY, Y ARTHOBA NAIK* and T V VENKATESHA \\ Department of Chemistry, School of Chemical Sciences, Kuvempu University, Shankaraghatta 577 451, India
}

MS received 17 June 2006; revised 15 November 2006

\begin{abstract}
Electro-polymerization of orthonitroaniline was carried out on graphite electrode in hydrochloric acid medium. Zinc-nickel alloy deposition was carried out in the presence of polynitroaniline in acid sulphate bath. The bath constituent and bath variables were optimized through Hull cell experiments. The current efficiency and throwing power were measured. High shift of potential towards more cathodic direction was observed in presence of addition agent. Corrosion resistance test revealed good protection of base metal by zinc-nickel coating obtained from the developed electrolyte. SEM photomicrograph shows fine-grained deposit in the presence of addition agent. The consumption of brightener in the lab-scale was $0.01 \mathrm{gL}^{-1}$ for $1000 \mathrm{amp}-\mathrm{h}$.
\end{abstract}

Keywords. Electrodeposition; electropolymerization; polynitroaniline; SEM studies; Zn-Ni alloy.

\section{Introduction}

Electroplated zinc coatings are considered as one of the many ways of corrosion protection of steel. Recently, interest in $\mathrm{Zn}-\mathrm{Ni}$ alloy coating has increased owing to its better mechanical and corrosion properties compared with pure zinc coatings (Shears 1989; Angelopoulos 2001; Brooks and Erb 2001; Muller et al 2002). The use of zinc and its alloys for improving the corrosion resistance of coated steel has been growing world wide (Sharples 1990; Alfantazi et al 1996; Vishalakshi Ravindran et al 2004) and as a substitute for toxic and high cost cadmium coating. In the automotive industry, for example, its use has been growing in search of increasing the corrosion resistance of chassis. The $\mathrm{Zn}-$ $\mathrm{Ni}$ alloy obtained by electrodeposition process with nickel varying between $8 \%$ and $14 \%$ by weight, give corrosion protection five to six times superior to that obtained with pure zinc deposits (Anicai et al 1992). The electrodeposition of $\mathrm{Zn}-\mathrm{Ni}$ alloy is classified by Brenner (1963) as an anomalous co-deposition where zinc, the less noble metal, is preferentially deposited. There are some propositions to explain the anomalous co-deposition of $\mathrm{Zn}-\mathrm{Ni}$ alloys. The first attributes the anomalous co-deposition to a local $\mathrm{pH}$ increase, which could induce zinc hydroxide precipitation and would inhibit nickel deposition (Higashi et al 1981; Fukushima et al 1988). It was, however, later that anomalous co-deposition occurred even at low current densities (Horans 1981), where hydrogen formation was unable to cause large alkalinization effects. Another proposition is based on the electrode potential deposition of zinc on nickel-

*Author for correspondence (drarthoba@ yahoo.co.in) rich zinc alloys or on nickel nuclei (Nicol and Philip 1976; Swathirajan 1986).

To get good bright deposit certain organic compounds are being used in the bath solution. Development of these brighteners for non-cyanide acid sulphate solution is continuously taking place even though few efficient commercial brighteners are available (Arthoba Naik et al 2001; Kariyanna et al 2003, 2004a, b; Abou-Krisha et al 2005; Kariyanna and Venkatesha 2005). It is evident from the available literature that the single addition agent generally does not produce good deposit over a wide current density range. In order to get good deposit, two or more addition agents are required (Abou-Krisha et al 2005). The presence of many addition agents poses problems in determining their consumption during plating. Also some of the addition agents cause pollution problem and health hazard (Arthoba Naik et al 2000; Arthoba Naik and Venkatesha 2003, 2005).

In the present work, efforts have been made to develop non-cyanide acid sulphate bath containing single brightener. Here, electrooxidative polymerization of orthonitroaniline was carried out on graphite electrode in 4M hydrochloric acid in a single compartment cell (Sachin et al 2005). Thus obtained polymer polynitroaniline (PNA) was subjected to Hull cell experiment. The polymer acts as a very good brightener and it is easily soluble in the bath solution.

\section{Experimental}

All the chemicals used were of LR grade and easily soluble in water. In the preparation of solutions, distilled water was used. The standard Hull cell of $267 \mathrm{~mL}$ capacity was used 
to optimize the bath constituents. The Hull cell experiments with the bath solution (table 1) were carried out without agitation. The $\mathrm{pH}$ of the solution was adjusted with $10 \%$ $\mathrm{H}_{2} \mathrm{SO}_{4}$ or sodium bicarbonate solution. Zinc plate of $99.99 \%$ purity was used as anode. The anode was activated each time by immersing in $10 \% \mathrm{HCl}$ followed by water wash. Mild steel plates (AISI-1079) of standard Hull cell size were mechanically polished to obtain a smooth surface and degreased by dipping in boiling trichloroethylene. The scales and dust on the steel plates were removed by dipping in $10 \% \mathrm{HCl}$ solution and were subjected to electrocleaning process. After this the steel plate was washed with water and used for the experiment as such. After the Hull cell experiment the plate was removed from the solution and subjected to bright dip in $1 \%$ nitric acid for 5-10 s followed by water wash. The nature and appearance of zinc plating was carefully studied and recorded through the Hull cell codes (figure 1).

All the experiments were conducted at $303 \pm 1 \mathrm{~K}$. The addition agent, PNA, was prepared by the electrochemical oxidation of orthonitroaniline. Graphite electrodes were used as anode and cathode. The electrolyte was $4 \mathrm{M} \mathrm{HCl}$ containing 0.04 M orthonitroaniline. The electrolysis was carried out at a current density of $1 \mathrm{~A} \mathrm{~cm}^{-2}$. After the completion of the electrolysis, the formed polymer was separated from the reaction medium, recrystallized from acetone and used for electrodeposition study. The addition agent, PNA, was dissolved in $100 \mathrm{~mL}$ ethyl alcohol $(0.2 \mathrm{~g} \mathrm{w} / \mathrm{v})$, prior to experiments and a known amount of this solution was added to the electroplating bath solution. The bath solution was stirred for $30 \mathrm{~min}$ and then subjected to Hull cell experiments.

The deposits were obtained at a constant current density from the optimized solutions in a rectangular methacrylate cell of capacity 2.51 . Polished, degreased and electrocleaned cathodes of $3 \times 4 \mathrm{~cm}^{2}$ were used. These plated steel cathodes were used to test the different properties and corrosion resistance of the deposit. Experiments were done in triplicate. Standard experimental procedures were adopted for the measurement of adherence, ductility, hardness etc. In all the above studies the average thickness of the deposit was $10 \mu \mathrm{m}$.

For corrosion resistance test, the coating with an average thickness was obtained on $3 \times 4 \mathrm{~cm}^{2}$ steel panels. Steel plates after deposition were given bright dip followed by passivation in a solution containing $200 \mathrm{gL}^{-1}$ of sodium dichromate and $2 \mathrm{mLL}^{-1}$ of sulphuric acid at $303 \mathrm{~K}$ for

Table 1. Basic bath composition and operating conditions.

\begin{tabular}{lcl}
\hline Constituents & Conc. $\left(\mathrm{gL}^{-1}\right)$ & \multicolumn{1}{c}{ Operating conditions } \\
\hline $\mathrm{ZnSO}_{4} \cdot 7 \mathrm{H}_{2} \mathrm{O}$ & 140 & Anode: zinc metal (99.99\%) \\
$\mathrm{NiSO}_{4}$ & 2 & Cathode: mild steel \\
$\mathrm{H}_{3} \mathrm{BO}_{3}$ & 10 & Temperature: $298 \mathrm{~K}$ \\
$\mathrm{Na}_{2} \mathrm{SO}_{4}$ & 80 & Cell current: $1 \mathrm{~A}$ \\
\hline
\end{tabular}

$10 \mathrm{~s}$. The chromated samples were dried for $24 \mathrm{~h}$ in a clean atmosphere before testing in a salt spray chamber in accordance with ASTM standard method B-117 using 5\% neutral $\mathrm{NaCl}$ solution (308 K).

A three-compartment cell was used for the polarization studies. The area of zinc anode was $2 \mathrm{~cm}^{2}$. The cathode was mild steel and the area exposed was $2 \mathrm{~cm}^{2}$. The cathode potential was recorded, galvanostatically, with respect to saturated calomel electrode at different current densities. For current efficiency and throwing power measurement, the Haring and Blum cell was used. For throwing power measurement the current distribution ratio between anode and cathode was $1: 5$. For determining consumption of brightener, a rectangular cell of 2.51 capacity was used. In all these experiments, $\mathrm{pH}$ of the solution before and after the experiments and the cell voltage at various operating conditions were recorded. SEM photomicrographs were taken to ascertain the nature of the deposit in presence of addition agent.

\section{Results and discussion}

\subsection{Hull cell studies}

3.1a Effect of polynitroaniline: Deposits obtained from Hull cell experiments with the basic bath solution containing zinc sulphate, sodium sulphate, CTAB and boric acid gave coarse dull deposit between the current density range of 0.5 and $3.5 \mathrm{Adm}^{-2}$ at $1 \mathrm{~A}$ cell current. To improve the nature of the deposit, polynitroaniline $(0 \cdot 2 \mathrm{~g} \mathrm{w} / \mathrm{v})$ was dissolved in $100 \mathrm{~mL}$ ethyl alcohol and a known volume of this solution was added to the bath. At low concentration of polynitroaniline the deposit was semibright between the current density range of 1 and $3 \mathrm{Adm}^{-2}$. At low current density, dull and at high current density, burnt deposits were obtained. With increase in the concentration of polynitroaniline, nature of deposit improved and at a concentration of $0.024 \mathrm{gL}^{-1}$ the Hull cell panels were bright between the current density range of 0.5 and $3.5 \mathrm{Adm}^{-2}$. Further increase in the concentration of polynitroaniline up to $0.04 \mathrm{gL}^{-1}$ does not affect the nature of the deposit, but above $0.04 \mathrm{gL}^{-1}$ gave dull deposit in the high current density region. Based on the above observation, the concentration of the polynitroaniline was kept at $0.024 \mathrm{gL}^{-1}$ as optimum. The Hull cell patterns are shown in figure 1a.

3.1b Effect of CTAB: The concentration of CTAB was varied from 2-8 $\mathrm{gL}^{-1}$, keeping the concentration of zinc sulphate at $140 \mathrm{gL}^{-1}$, nickel sulphate at $4 \mathrm{gL}^{-1}$, sodium sulphate at $80 \mathrm{gL}^{-1}, \mathrm{PNA}$ at $0.024 \mathrm{gL}^{-1}$ and boric acid at $10 \mathrm{gL}^{-1}$. At low concentration of CTAB, the nature of deposit was semibright in the current density range of $0.3-$ $3.5 \mathrm{Adm}^{-2}$. Above $3.5 \mathrm{Adm}^{-2}$ burnt deposit was observed. With increase in the concentration of CTAB from $1-8 \mathrm{gL}^{-1}$, burnt area was reduced and at a concentration of $2 \mathrm{gL}^{-1}$, 


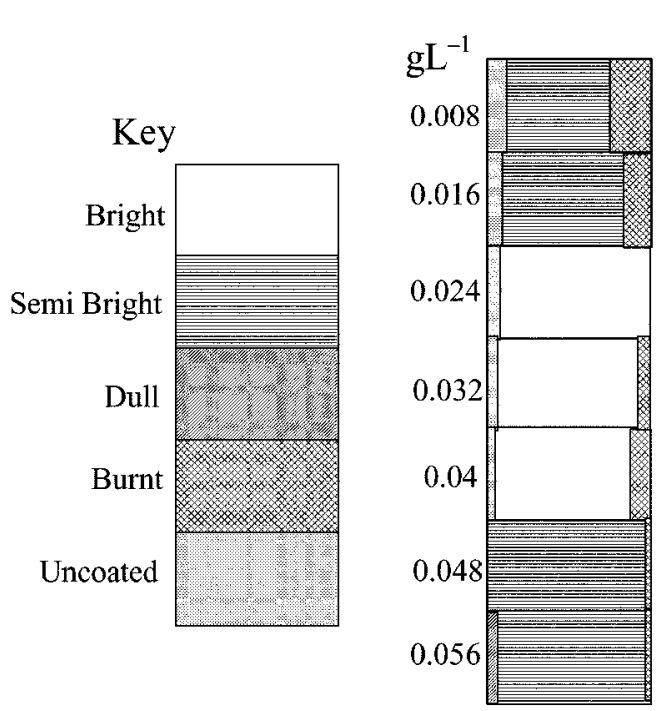

(a)

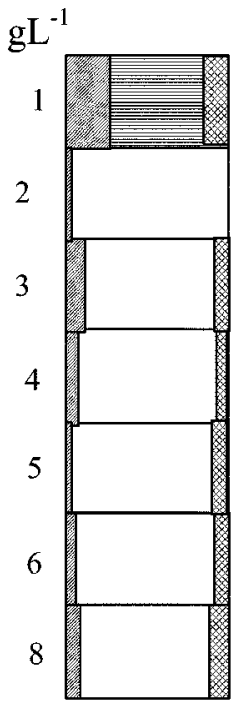

(b)
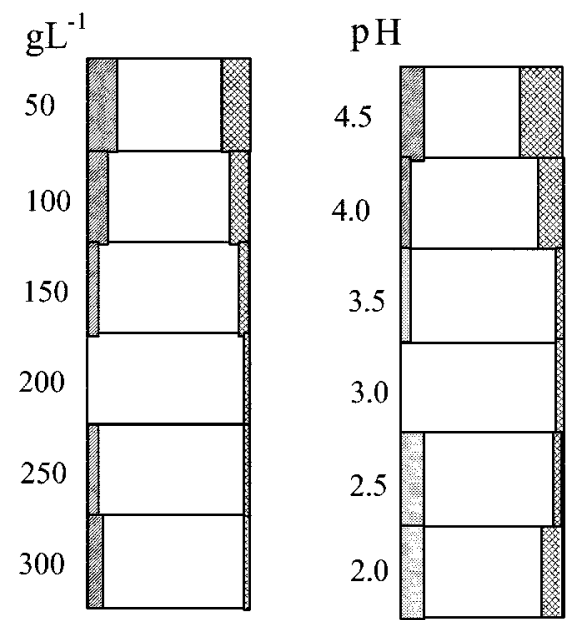

(d)

(c)

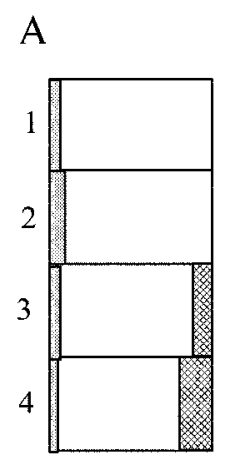

(e)

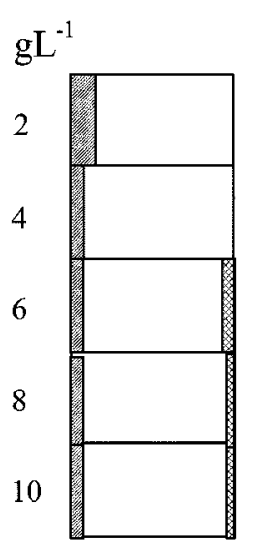

(f)
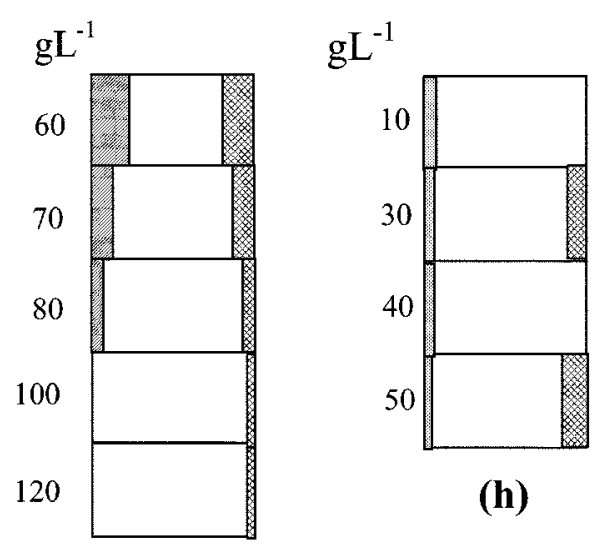

(h)

(g)

Figure 1. Hull cell figures: (a) PNA, (b) CTAB, (c) $\mathrm{ZnSO}_{4} \cdot 7 \mathrm{H}_{2} \mathrm{O}$, (d) $\mathrm{pH}$, (e) current $(A)$, (f) $\mathrm{NiSO}_{4} \cdot 7 \mathrm{H}_{2} \mathrm{O},(\mathbf{g}) \mathrm{Na}_{2} \mathrm{SO}_{4}$ and $(\mathbf{h})$ $\mathrm{H}_{3} \mathrm{BO}_{3}$.

bright deposit was obtained in the current density range of $0 \cdot 4-3 \cdot 5 \mathrm{Adm}^{-2}$ and above this concentration no change in the nature of deposit was observed. Therefore, the concentration of CTAB was fixed at $2 \mathrm{gL}^{-1}$ as optimum in the bath solution. The Hull cell patterns are shown in figure $1 b$.

3.1c Effect of zinc sulphate: To know the effect of zinc metal ion concentration, the zinc sulphate concentration was varied from $50 \mathrm{gL}^{-1}-300 \mathrm{gL}^{-1}$, keeping the concentration of sodium sulphate at $80 \mathrm{gL}^{-1}$, boric acid at $10 \mathrm{gL}^{-1}$ and CTAB at $2 \mathrm{gL}^{-1}$. At lower concentration of zinc sulphate, bright deposit was observed in the current density range between 1 and $3 \mathrm{Adm}^{-2}$. At low current density range $\left(<1 \mathrm{Adm}^{-2}\right)$, a thin deposit and above $3 \mathrm{Adm}^{-2}$ burnt deposit was observed. It was noticed that the Hull cell patterns were almost free from burnt deposit when the concentration of zinc sulphate reached $200 \mathrm{gL}^{-1}$. At still higher concentrations (> $200 \mathrm{gL}^{-1}$ ), there was no change in the nature of deposit. Influence of the concentration of zinc sulphate on Hull cell patterns is shown in figure 1c. The concentration of zinc sulphate was fixed at $200 \mathrm{gL}^{-1}$ as optimum.

3.1d Effect of $p H$ : In order to study the effect of $\mathrm{pH}$ on nature of deposit, the $\mathrm{pH}$ of the bath solution was varied from 2-5. At low $\mathrm{pH}$ between 2 and $2 \cdot 5$, the Hull cell pattern showed burnt deposit at high current density region and uncoated area on low current density region. At $\mathrm{pH} 3$, satisfactory results were obtained and the specimens were completely free from burnt and uncoated regions. With increase in $\mathrm{pH}$ above 4 the deposit became dull and cloudy. By these observations the $\mathrm{pH}$ of the solution was fixed at 3 in the bath solution. The effect of $\mathrm{pH}$ on the nature of deposit is shown in figure $1 \mathrm{~d}$. 
3.1e Effect of cell current: The Hull cell experiments were carried out at different cell currents (1-3 A) for 5 min using optimized bath solution. It was found that at a cell current of $1 \mathrm{~A}$, the deposit was bright in the current density range $0 \cdot 3-4 \mathrm{Adm}^{-2}$. At a cell current of $2 \mathrm{~A}$ and $3 \mathrm{~A}$ the bright current density area was reduced and the high current density region was covered with burnt deposit. From these observations it was found that the optimized bath produces bright deposition in the current density range of $0 \cdot 3-4 \mathrm{Adm}^{-2}$. The Hull cell patterns are shown in figure $1 \mathrm{e}$.

3.1f Effect of nickel sulphate: To find out the effect of nickel metal ion concentration, nickel sulphate was varied from $2-10 \mathrm{gL}^{-1}$ by keeping the concentration of PNA at $0.024 \mathrm{gL}^{-1}$, zinc sulphate at $200 \mathrm{gL}^{-1}$, sodium sulphate at $100 \mathrm{gL}^{-1}$, boric acid at $40 \mathrm{gL}^{-1}$ and CTAB at $2 \mathrm{gL}^{-1}$. At lower concentration of nickel sulphate $\left(<1 \mathrm{gL}^{-1}\right)$, bright deposit was observed in the current density range between 1 and $3.5 \mathrm{Adm}^{-2}$. With increase in the concentration of nickel sulphate (up to $4 \mathrm{gL}^{-1}$ ), bright deposit was extended in the current density range of $0 \cdot 5-4 \mathrm{Adm}^{-2}$, with further increase in the nickel sulphate concentration in the bath solution, a reduction in the bright current density range and increase in the uncoated and burnt area was observed. Based on the observation the concentration of nickel sulphate in the bath solution was fixed at $4 \mathrm{gL}^{-1}$ as optimum. The effect of nickel sulphate concentration on nature of deposit is shown in figure $1 \mathrm{f}$.

3.1g Effect of sodium sulphate: Sodium sulphate was added to increase the conductance of the bath solution. The concentration of sodium sulphate was varied from 80$100 \mathrm{gL}^{-1}$ by keeping concentration of PNA at $0.024 \mathrm{gL}^{-1}$, zinc sulphate at $200 \mathrm{gL}^{-1}$, boric acid at $40 \mathrm{gL}^{-1}$ and $\mathrm{CTAB}$ at $2 \mathrm{gL}^{-1}$. At lower concentration of sodium sulphate $\left(<80 \mathrm{gL}^{-1}\right)$, the Hull cell panels showed burnt deposit at higher current density region and uncoated at low current density region. The burnt and uncoated regions were found to be reduced when the concentration of nickel sulphate was increased above $80 \mathrm{gL}^{-1}$, when the concentration of sodium sulphate reached $100 \mathrm{gL}^{-1}$, the deposit was bright over the current density region of $0 \cdot 3-4 \mathrm{Adm}^{-2}$. Further increase of sodium sulphate concentration does not have any effect on the nature of the deposit. Based on the above observation the concentration of sodium sulphate was fixed at $100 \mathrm{gL}^{-1}$ as optimum. The effect of sodium sulphate concentration on nature of deposit is shown in figure $1 \mathrm{~g}$.

3.1h Effect of boric acid: The aim of addition of boric acid to the electroplating bath was to control variation of $\mathrm{H}^{+}$ion concentration in the bath solution. To see the optimum concentration of boric acid, the concentration was varied from $10-50 \mathrm{gL}^{-1}$ by keeping the concentration of other addition agents at optimum concentrations. At lower concen- tration of boric acid $\left(<10 \mathrm{gL}^{-1}\right)$, the deposit was bright over the current density range between 0.5 and $3 \mathrm{Adm}^{-2}$. The bright area was extended between the current density range of 0.5 and $4 \mathrm{Adm}^{-2}$ when the concentration of boric acid was $40 \mathrm{gL}^{-1}$. Higher concentration of boric acid will not cause any effect on the Hull cell pattern. So the concentration of boric acid was fixed at $40 \mathrm{gL}^{-1}$. The effect of boric acid on nature of deposit is shown in figure $1 \mathrm{~h}$.

\subsection{Current efficiency and throwing power}

Current efficiency and throwing power were measured at different current densities by using optimized bath solution. The current efficiency was measured by taking a rectangular methacrylate cell. At lower current density $\left(1 \mathrm{Adm}^{-2}\right)$, the current efficiency was found to be $93 \%$. At a current density of $3 \mathrm{Adm}^{-2}$, the efficiency was increased to $94.6 \%$. With increase in the current density above $4 \mathrm{Adm}^{-2}$, the current efficiency was found to be decreased and at $5 \mathrm{Adm}^{-2}$ it was $87 \cdot 2 \%$.

Throwing power was measured by using Haring and Blum cell at different current densities. At lower current densities the throwing power was $21 \%$ and with increase in the current density it was increased to $22 \cdot 4$ (table 2).

\subsection{Polarization study}

The potential of steel cathode was measured galvanostatically with respect to saturated calomel electrode, at different current densities. Cathodic polarizations were measured using the bath solution with and without addition agents. The variation of cathode potential with current density is shown in figure 2. At any given current density, the cathode potential became more negative in presence of CTAB. This shift was still higher in presence of polynitroaniline. In many electroplating baths surfactants are being used as addition agents. These addition agents change the behaviour of cathode surfaces by adsorbing on the surface of the cathodes. The compound, CTAB, produces uniform deposit and thereby acts as a leveller.

PNA is a macromolecule, which contains the electroactive functional groups such as $-\mathrm{C}=\mathrm{N}-$ and $-\mathrm{NH}$ groups. In the bath solution it forms complex with $\mathrm{Zn}$ and $\mathrm{Ni}$ metal ions and controls the rate of metal deposition. The deposition

Table 2. Current efficiency and throwing power at different current densities.

\begin{tabular}{lcc}
\hline $\begin{array}{l}\text { Current density } \\
\left(\mathrm{Adm}^{-2}\right)\end{array}$ & $\begin{array}{c}\text { Current efficiency } \\
(\%)\end{array}$ & $\begin{array}{c}\text { Throwing power } \\
(\%)\end{array}$ \\
\hline 1 & $93 \cdot 0$ & $21 \cdot 0$ \\
2 & $93 \cdot 8$ & $21 \cdot 6$ \\
3 & $94 \cdot 6$ & $22 \cdot 4$ \\
4 & $92 \cdot 0$ & $22 \cdot 0$ \\
5 & $87 \cdot 2$ & $21 \cdot 6$ \\
\hline
\end{tabular}




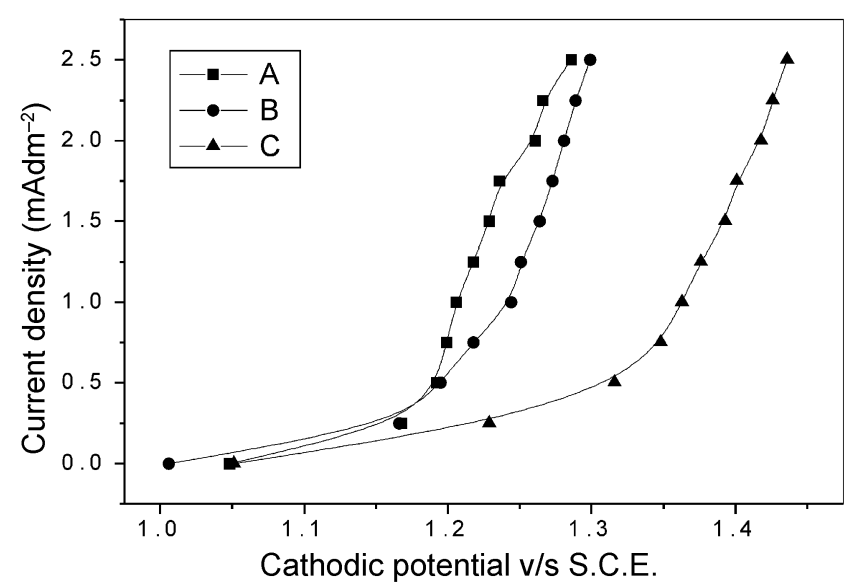

Figure 2. Effect of addition agents on cathodic potential $(\mathrm{A}=\mathrm{B}$ asic bath $(\mathrm{BB}), \mathrm{B}=\mathrm{BB}+\mathrm{CTAB}, \mathrm{C}=\mathrm{BB}+\mathrm{CTAB}+$ PNA).

potential for metal ions in presence of PNA shifted to more (-) direction and leads to regular and uniform crystallization.

\subsection{Corrosion resistance}

Mild steel panels of $2 \times 2 \mathrm{~cm}^{2}$ area were polished, degreased and treated with $10 \%$ hydrochloric acid followed by water wash. These plates were plated with zinc-nickel alloy from optimum plating bath at different current densities. In presence of addition agents, the deposits were pore-free in nature above a thickness of $5 \mu \mathrm{m}$ as indicated by ferroxyl test. In absence of addition agents, the coating was highly porous even at a thickness of $10 \mu \mathrm{m}$.

The corrosion resistance of zinc-nickel alloy plated steel plates were tested by salt spray method (ASTM B$117)$. Mild steel plates $\left(5 \times 5 \mathrm{~cm}^{2}\right)$ were coated with zincnickel alloy from the optimum bath solution. These plates were given bright dip in $1 \%$ nitric acid followed by chromate passivation. Before subjecting to the salt spray test, the plates were kept in a clean and dry atmosphere for $24 \mathrm{~h}$. Even after $120 \mathrm{~h}$ of salt spray test no white rust was observed on the specimens. This indicated good corrosion resistance of the deposit.

\subsection{Metallurgical properties}

An important property of an electrodeposit is its adhesion to the base metal. Usually, zinc-nickel deposits on mild steel have very good adhesion. To measure adherence, the zinc deposits of 10-20 $\mu \mathrm{m}$ thickness were obtained under optimum conditions of plating bath on mild steel plates $\left(1 \times 10 \mathrm{~cm}^{2}\right)$. These plated specimens were subjected to bend test through $90^{\circ}$ and finally through $180^{\circ}$. Even after $180^{\circ}$ bending no crack or peel off was observed in the deposit. This reveals good adhesion of zinc deposit to the substrate. The more useful method for measuring microhardness involves making an indentation with an indenter of specified geometry under a specified load. The length of indentation is expressed in Vickers hardness number (VHN). Zinc-nickel alloy was electroplated on mild steel panels up to a thickness of $20 \mu \mathrm{m}$ and a load of $50 \mathrm{~g}$ was employed. The microhardness of zinc-nickel alloy was found to be 130 .

\subsection{SEM studies}

SEM photomicrographs of zinc-nickel alloy deposit obtained from basic bath solution with and without addition agents are shown in figure 3 . These indicate that the basic bath produced only coarse-grained deposits. The grain size was refined further in presence of addition agents. Fine-grained smooth deposit was obtained from the bath solution containing an optimum concentration of all the addition agents.

\subsection{Consumption of brightener}

To know the amount of addition agents consumed in the bath, $2.5 \mathrm{~L}$ of bath solution was taken and plating was carried out at different current densities. The total number of coulombs passed to the bath solution was recorded at a time when the bath just started to give semibright deposit. The bath solution after use was subjected to Hull cell test by adding different amounts of polynitroaniline. The concentration of polymer, at which once again bright deposit was obtained, was determined. The amount of polynitroaniline consumed for 1000 amps-h was $0.01 \mathrm{gL}^{-1}$.

\subsection{Pilot plant study}

The commercial applicability of the developed bath was explored by performing the plating experiments in a vat bath of $25 \mathrm{~L}$ capacity. The bath solution with optimum concentration of bath constituents was prepared. Steel components of different sizes and shapes (plates, rods, nuts, bolts, small pipes, clamps, etc) were degreased, electrocleaned and given acid dip followed by water wash. These treated components were rigged by copper wire and connected to the negative terminal of d.c. source. Electroplating was carried out at different current densities with and without agitation of the bath solution. The components after deposition were removed from the plating vat and subjected to bright dip and passivation. The passivated articles were subjected to corrosion resistance test in a salt spray chamber. Adhesion of the deposit to the substrate was good as it was confirmed by bend test and hear test methods. The components of irregular shapes plated under stirred and unstirred conditions showed no rust at the recesses 

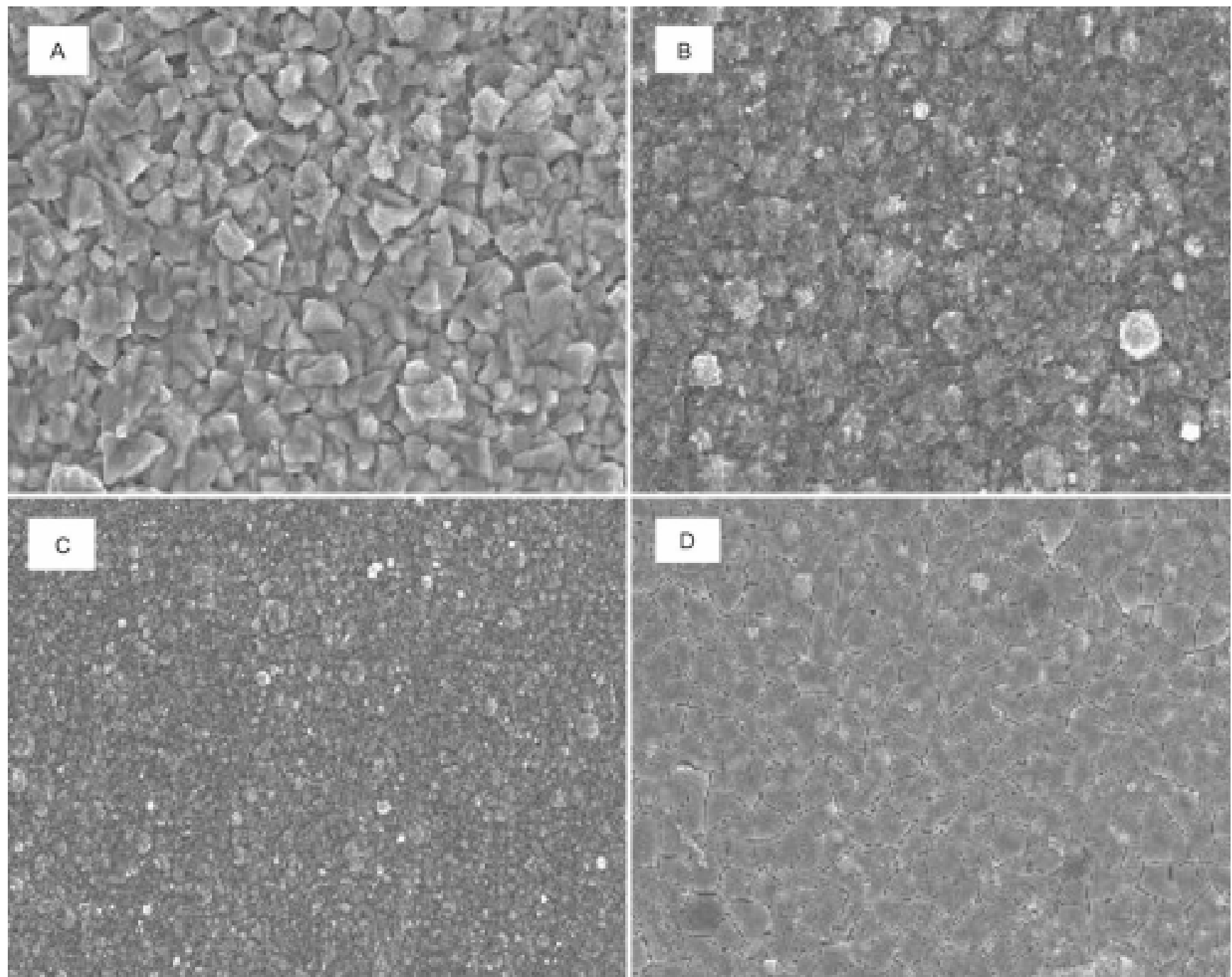

Figure 3. SEM photomicrographs obtained at a current density of $3.5 \mathrm{Adm}^{-2}$ : A. Basic bath (BB), B. BB + CTAB, C. BB + CTAB + PNA and D. passivated deposit.

Table 3. Optimum bath composition and conditions.

\begin{tabular}{lcl}
\hline Bath constituents & Range & \multicolumn{1}{c}{ Operating conditions } \\
\hline $\mathrm{ZnSO}_{4} \cdot 7 \mathrm{H}_{2} \mathrm{O}\left(\mathrm{gL}^{-1}\right)$ & 200 & Anode: zinc metal $(99 \cdot 99 \%)$ \\
$\mathrm{NiSO}_{4} \cdot 7 \mathrm{H}_{2} \mathrm{O}\left(\mathrm{gL}^{-1}\right)$ & 4 & Cathode: mild steel \\
$\mathrm{PNA}_{\left(\mathrm{gL}^{-1}\right)}$ & $0 \cdot 024$ & Temperature: $293-303 \mathrm{~K}$ \\
$\mathrm{Na}_{2} \mathrm{SO}_{4}\left(\mathrm{gL}^{-1}\right)$ & 100 & Bright current density range: $0 \cdot 5-4 \mathrm{Adm}^{-2}$ \\
$\mathrm{H}_{3} \mathrm{BO}_{3}\left(\mathrm{gL}^{-1}\right)$ & 40 & Agitation: air \\
$\mathrm{CTAB}\left(\mathrm{gL}^{-1}\right)$ & 2 & \\
\hline
\end{tabular}

even after $98 \mathrm{~h}$ of salt spray test. This indicated the ability of the bath to produce uniform deposit on the components of irregular shape.

\section{Conclusions}

The developed bath produces good deposit over the current density range of $0.4-3.5 \mathrm{~A} \mathrm{dm}^{-2}$. The optimized bath composition is shown in table 3 . The throwing power is reasonably good. The brightener can be easily synthe- sized. The addition agents are non-toxic, easily soluble in water and hence require no treatment of the effluent. The deposit is pore-free and corrosion resistant. The bath could be easily commercialized.

\section{Acknowledgement}

The authors are grateful to the authorities of Kuvempu University for providing necessary laboratory facilities. 


\section{References}

Abou-Krisha M M, Zaky A M and Toghan A A 2005 J. Corr. Sci. \& Engg. 71

Alfantazi A M, Page J and Urb U 1996 J. Appl. Electrochem. 261225

Angelopoulos M 2001 IBM J. Res \& Dev. 4557

Anicai L, Siteavu M and Grunwald E 1992 Corros. Prevent. Control 3989

Arthoba Naik Y and Venkatesha T V 2003 Indian J. Chem. Technol. 10318

Arthoba Naik Y and Venkatesha T V 2005 Bull. Mater. Sci. 28 495

Arthoba Naik Y, Venkatesha T V and Vasudeva Nayak P 2000 Bull. Electrochem. 16481

Arthoba Naik Y, Venkatesha T V and Vasudeva Nayak P 2001 Indian J. Chem. Technol. 8390

Brenner A 1963 Electrodeposition of alloys (New York: Academic Press) 2 p. 194

Brooks I and Erb U 2001 Scr. Mater. 44853

Fukushima H, Akiyama T and Higashi K 1988 Metallurgy 42242
Higashi K, Fukushima H, Takayushi V, Adaniya T and Matsudo K 1981 J. Electrochem. Soc. 1282091

Horans J 1981 J. Electrochem. Soc. 12845

Kariyanna K G and Venkatesha T V 2005 Bull. Electrochem. 21 547

Kariyanna K G, Arthoba Naik Y and Venkatesha T V 2003 J. Indian Council Chem. 2043

Kariyanna K G, Arthoba Naik Y and Venkatesha T V 2004a Bull. Electrochem. 2039

Kariyanna K G, Arthoba Naik Y and Venkatesha T V 2004b Trans. SAEST 3939

Muller C, Sarret M and Benballa M 2002 J. Electroanal. Chem. 51985

Nicol M J and Philip H I 1976 J. Electroanal. Chem. 70233

Sachin H P, Ganesha Achary, Arthoba Naik Y and Venkatesha T V 2005 J. Teach. Res. Chem. 121

Sharples T E 1990 Prod. Finish. 5438

Shears A P 1989 Trans. IMF 6767

Swathirajan S 1986 J. Electrochem. Soc. 133671

Vishalakshi Ravindran, Sridevi R, Rajakumari R, Sekar R and Muralidharan V S 2004 Indian J. Chem. Technol. 11465 